\title{
Mobile Phone Carrier Construction of Ideological and Political Education of College Students under the Background of $4 G$ Network
}

\author{
Yang Li ${ }^{1, a}$ \\ ${ }^{1}$ Student Affairs Department, Jilin Business and Technology College, Changchun City, Jilin \\ Province, China,130507 \\ a email:
}

Keywords: 4G Network, College Students, Ideological and Political Education, Mobile Phone Carrier, New Model

\begin{abstract}
In the operation of $4 \mathrm{G}$ network, the information dissemination speed of mobile phone is faster, and the information processing ability is stronger, which provides some favorable conditions for the construction of mobile phone carrier of ideological and political education for college students. Based on the author's teaching experience, this paper analyzed the strategies for the construction of mobile phone carriers under the background of 4G network, and made some specific development countermeasures - Building a new model, expanding a new way and establishing a long-term mechanism of ideological and political education in mobile media. The research results of this paper will provide a new idea for the traditional ideological and political education of college students.
\end{abstract}

\section{Introduction}

Since entering the 4G era, with the emergence of mobile phone newspapers, mobile phone TV, mobile phone movies, mobile phone radio and other forms of communication, the mobile phone media has gradually evolved into an important culture, entertainment, media platforms, and has became one of the most powerful, the most widely used, the most convenient public media. Actively exploring the emerging cultural phenomenon of mobile media, with the help of mobile media technology, carefully building a mobile phone media based college students' ideological and political education platform, taking the initiative to occupy the new position of ideological and political education of college students have important significance for strengthening the innovation of Ideological and political education mode and strengthening the timeliness and effectiveness of ideological and political education of college students.

\section{Building a New Model of Ideological and Political Education in Mobile Phone Media}

The concept of mobile phone media in the ideological and political education. Mobile media ideological and political education is a new type of education, which means that the individuals and teams of ideological and political education workers in colleges and universities conduct the education with the help of modern mobile media platform, to provide relevant information about ideological and political education workers and college students to study, work, life and so on. Mobile phone media will increasingly become a new carrier of higher education, especially in the 
ideological and political education, and it will change the mode of communication of ideological and political education in colleges and universities to a large extent.

The ideological and political education function of mobile phone media. Instant messaging inbox. Using mobile media to solve the students' confusion, to help solve practical problems encountered by College Students; Through the mobile phone network, exchanging the ideas of hot news, current events, and cultural perspectives; Using WeChat information within the group, to improve the efficiency of College Students' personal information management. Demonstration education browser. Ideological and political education workers can fully combine the mobile media application platform to realize the function of management and service and build a new carrier of ideological and political work, injecting new content into the ideological and political work. For example, based on the major festivals, major events, advanced people and advanced deeds, preparing the related short message and sending it to the students, carrying out the ideological education, so that the mobile phone media to carry the classroom, acting as a demonstration of the educational browser. Shortcut keys for communication of the teachers and students. By mobile QQ, WeChat and other mobile media, teachers and students can make real communication, with no role gap, no age difference, which can ease the psychological alert, so that students can really open their hearts. From the students most concerned issues, such as the employment, work, study and life, teachers do practical, problem-solving things for the students, in equality, sincere exchanges, to shortcut the education effect. Student oriented navigator. With a wide range of mobile media information dissemination platform, the professional information of all kinds of subjects, such as subject contest, students' science and technology innovation project, research section, employment recruitment and all kinds of lecture information, can be quickly passed to the majority of students, so that students can have a real-time dynamic grasp of the professional field of study, and seize the opportunity to adapt to the needs of the community.

\section{A New Way to Expand the Ideological and Political Education with the help of Mobile Phone Media}

Setting up WeChat platform to lead the direction of the media. WeChat has infiltrated all aspects of student life, so with WeChat, it can build a full range of campus information integration platform for communication. Through the main means of mass mobile phone, covering the whole school range of wireless terminal network carrier. With the help of WeChat, selectting the targeted group model, it can timely and effectively achieve transmission of information, so that the majority of students can get a clear, reliable information in the first time. Improving the boring atmosphere of ideological and political education will play a positive effect of education.

Establishment of monitoring and management, correct identification of information. Mobile phone is a kind of great coverage, wide spread, resulting in a great impact on the wireless transmission of the media, but it is inevitable that there will be a lot of noise in the spread of the spread of beneficial health information to people's lives. How to purify the mobile phone environment and control noise in the controllable range, and to guide students to the correct information channels, are the questions that must be faced in the ideological and political education of mobile phone media. Through the establishment of a standardized and effective mobile phone network security management, standardize information dissemination, in college students unequivocally strengthen socialist core value view education, to guide college students to establish a correct cultural outlook, improve students' cultural immunity and judgment.

Setting up the theme window, cultivating the aesthetic taste. Mobile media has the characteristics of readability, interactivity and novelty. Rich forms of text messaging, MMS, WAP 
and IVR enable mobile media can publish pictures, audio, video and taste of news and information to meet the user's personalized demand. Through the involvement of mobile media, the traditional ideological and political propaganda mode has changed a great change. The multimedia mobile phone newspaper, magazine that is closer to the class of students, gradually affected the aesthetic taste of College Students, at the same time, it arouse the interest of reading. Seizing the opportunity to make the boring theory vivid, make the offensive sermon perceptual, actively cultivate students to improve the noble personality, to shape the perfect human nature.

Establishing a communication link to conduct health psychology. The virtual nature and personal nature of mobile media greatly shorten the time and space of the ideological and political education situation. All along, the sense of trust between educators and the educated, affect and restrict the effect and quality of ideological and political education. Mobile media communication technology is breaking the boundaries between the real world and the virtual world, through the new mode of communication of the "people - screen", it has set up the soft environment of interpersonal communication which spans time and space, narrowing the psychological distance of interpersonal communication, reducing the psychological prevention of interpersonal activities. This allows students to have a mental health communication platform, sets up a harmonious and harmonious mind communication link for the teachers and students, so that ideological and political education is more affinity.

\section{Establish the Long Term Mechanism of the Ideological and Political Education of Mobile Media}

Paying attention to the role of the media and strengthening the awareness of the means of mobile education. In early 2009, Central Committee put forward that enriching means and carrier of the work of the Communist Youth League relying on new media. Adapt to the new features of youth communication, communication, contact and gathering, through the online interactive community, blog, instant messaging system, mobile phone text messages, mobile phone newspapers and other ways, to explore the effective way of public opinion guidance and ideological education through the new media, and sum up the mode of using the network platform to organize and mobilize the youth. In the mode of ideological and political education to adapt to the development of the new century, the abilities of the ideological and political education worker using mobile phone media directly determines the ideological and political education in the process of mobile media awareness, use and development. Therefore, the ideological and political education workers should pay attention to the new media, mobile media, understand the current situation of the application of mobile media, to master certain knowledge of mobile media, to meet the new challenges of Ideological and political education in the era of mobile media.

Grasping the personality characteristics and focusing on the subject status of College Students. Modern college students have a strong sense of self - consciousness, showing the behavior of the pursuit of publicity, but the heart needs recognition of the characteristics, which is a new challenge for the current ideological and political work. Therefore, in practical work, it needs to fully take the development of students as the center, respect the subject position and function of the students in the ideological and Political Education. Eliminate communication barriers between students and teachers, students and schools, students and society through mobile media, embody the freedom and independence of individual and the choice and utilization of information, to make college students pursue freedom, equality, open communication. At the same time, let the audience truly appreciate the influence of being respected and loved to narrow the distance between teachers and students, to establish a two-way exchange of information interactive platform. 
Playing the unique advantage and building a mobile phone education model. For the mobile phone media, it needs to establish and improve the characteristics of the targeted education model, cling to many of the attributes of the mobile media. First, timeliness advantage, embody the emergency response mechanism of the short message medium, timely transforming earthquake, snow and other unexpected events of the disaster information; Second, the advantage of life, according to the characteristics of most people mobile phone, pull the advantages of mobile phone's life into the traditional ideological education, through illustrated regularly send mobile phone, mobile phone aphorisms column, makes the characteristics of fixed pattern of ideological and political education in political gradually fade out. Third, interactive advantages, with the characteristics of mobile communication, it can actively carry out healthy, lively and vivid mobile phone cultural activities.

\section{Conclusion}

Faced with the new media environment, ideological and political education workers should pay attention to the mobile media, actively occupy the new carrier of ideological and political work in Colleges and Universities. As the ideological and political workers in Colleges and universities, we should face the opportunities and challenges brought by the development of mobile media, strengthen the development and application of mobile media in the field of ideological and political education, make it become a new platform for College Students, to realize the innovation of education methods, to create a new situation of Ideological and political education, to provide intellectual support and talent support for the construction of a democratic and harmonious socialist country.

\section{References}

[1] Ye Shanqing, Zheng Xiaoyi. Relying on mobile media to promote the ideological and political education of college students thinking [J]. Social Science (new theory Edition), 2012,02:246-247.

[2] Shen Nan. The influence of mobile media on the ideological and political education of college students and its application [J]. Journal of Career Technical College in Jiangsu, 2015,04:105-108.

[3] Wu Fengyun. Exploration of Ideological and political education in Colleges and Universities Based on mobile media [J]. Journal of Kaifeng Institute of Education, 2014,10:225-226.

[4] Wang Yu, He Xiaoping, Hu Tao. The negative impact of mobile phone on College Students' Ideological and political education and Its Countermeasures [J]. Journal of Jiangxi Normal University (PHILOSOPHY AND SOCIAL SCIENCE EDITION), 2013,03:131-134.

[5] Yang Zhongdong. The predicament and outlet of the ideological and political work of University under the information of mobile network [J]. Education and Career, 2014,06:76-77. 